\title{
Towards a theory of regional diversification: combining insights from Evolutionary Economic Geography and Transition Studies
}

\section{Ron Boschma, Lars Coenen, Koen Frenken \& Bernhard Truffer}

To cite this article: Ron Boschma, Lars Coenen, Koen Frenken \& Bernhard Truffer (2017) Towards a theory of regional diversification: combining insights from Evolutionary Economic Geography and Transition Studies, Regional Studies, 51:1, 31-45, DOI: 10.1080/00343404.2016.1258460

To link to this article: http://dx.doi.org/10.1080/00343404.2016.1258460

曲 Published online: 05 Jan 2017.

Submit your article to this journal

WII Article views: 1146

Q View related articles ¿ત

View Crossmark data \lceil

4 Citing articles: 2 View citing articles 주다. 


\title{
Towards a theory of regional diversification: combining insights from Evolutionary Economic Geography and Transition Studies
}

\author{
Ron Boschma ${ }^{\mathbf{a}}$, Lars Coenen ${ }^{\mathbf{b}} \odot$, Koen Frenken ${ }^{\mathbf{c}}$ and Bernhard Truffer ${ }^{\mathbf{d}} \odot$
}

\begin{abstract}
Towards a theory of regional diversification: combining insights from Evolutionary Economic Geography and Transition Studies. Regional Studies. This paper develops a theoretical framework of regional diversification by combining insights from Evolutionary Economic Geography and Transition Studies. It argues that a theory of regional diversification should not only build on the current understanding of related diversification but also account for processes of unrelated diversification by looking at the role of agency in processes of institutional entrepreneurship, and at enabling and constraining factors at various spatial scales. This paper proposes a typology of four regional diversification trajectories by cross-tabulating related versus unrelated diversification with niche creation versus regime adoption, and it develops a number of propositions.
\end{abstract}

\section{KEYWORDS}

Evolutionary Economic Geography; Transition Studies; regional diversification; unrelated diversification; institutional entrepreneurship; institutional change

\section{摘要}

迈向区域多样化的理论：结合演化经济地理学与变迁研究的洞见。Regional Studies。本文透过结合演化经济地理学和 变迁研究的洞见, 建立一个区域多样化的理论架构。本文主张, 区域多样化的理论, 不应只是建立在当前对于相关多 样化的理解之上, 而应同时透过检视行动者在制度革新过程中的角色, 以及在各种空间尺度上的协助与限制因素, 考 量非相关多样化的过程。本文透过将相关多样化相对于非相关多样化, 以及利基创造相对于体制採纳进行交叉製表, 提出四大区域多样化轨迹的类型学, 并发展若干的主张。

关键词

演化经济地理学; 变迁研究; 区域多样化; 非相关多样化; 制度革新; 制度变迁

\section{RÉSUMÉ}

Vers une théorie de la diversification régionale: combinant des aperçus provenant de la géographie économique évolutionniste et des études sur la transition. Regional Studies. Cet article développe un cadre théorique de la diversification régionale en combinant des aperçus provenant de la géographie économique évolutionniste et des études sur la transition. On affirme ici qu'une théorie de la diversification régionale devrait reposer non seulement sur la compréhension actuelle de la diversification associée mais devrait tenir compte aussi des processus de diversification sans rapport en examinant le rôle que joue la représentation dans les processus de l'esprit d'entreprise institutionnel, et les facteurs favorables et défavorables à diverses échelles spatiales. Cet article propose une typologie de quatre

\section{CONTACT}

a (Corresponding author) ron.boschma@circle.lu.se

Section of Economic Geography, Urban and Regional Research Centre Utrecht (URU), Faculty of Geosciences, Utrecht University, Utrecht, the Netherlands; and Centre for Innovation, Research and Competence in the Learning Economy (CIRCLE), Lund University, Lund, Sweden.

${ }^{\mathbf{b}}$ lars.coenen@circle.lu.se

Centre for Innovation, Research and Competence in the Learning Economy (CIRCLE), Lund University, Lund, Sweden; and Melbourne Sustainable Society Institute, Faculty of Architecture, Building and Planning, The University of Melbourne, Parkville, VIC, Australia.

c@k.frenken@uu.nl

Innovation Studies, Copernicus Institute of Sustainable Development, Faculty of Geosciences, Utrecht University, Utrecht, the Netherlands.

d@ bernhard.truffer@eawag.ch

Eawag (Swiss Federal Institute of Aquatic Science and Technology), Department of Environmental Social Science, Dübendorf, Switzerland; Section of Economic Geography, Urban and Regional Research Centre Utrecht (URU), Faculty of Geosciences, Utrecht University, Utrecht, the Netherlands; and Innovation Studies, Copernicus Institute of Sustainable Development, Faculty of Geosciences, Utrecht University, Utrecht, the Netherlands. 
trajectoires de diversification régionale en effectuant une tabulation croisée de la diversification associée et la diversification sans rapport avec la création et l'adoption de créneaux, et on élabore un nombre de propositions.

\section{MOTS-CLÉS}

géographie économique évolutionniste; études sur la transition; diversification régionale; diversification sans rapport; esprit d'entreprise institutionnel; changement institutionnel

\section{ZUSAMMENFASSUNG}

Auf dem Weg zu einer Theorie der regionalen Diversifizierung: Kombination von Erkenntnissen aus der evolutionären Wirtschaftsgeografie und von Übergangsstudien. Regional Studies. In diesem Beitrag entwickeln wir durch die Kombination von Erkenntnissen aus der evolutionären Wirtschaftsgeografie und von Übergangsstudien einen theoretischen Rahmen der regionalen Diversifizierung. Wir argumentieren, dass eine Theorie der regionalen Diversifizierung nicht nur auf dem derzeitigen Verständnis der verwandten Diversifizierung aufbauen, sondern auch Abläufe der unverwandten Diversifizierung berücksichtigen sollte, indem sie die Rolle der Wirkmächtigkeit in Abläufen des institutionellen Unternehmertums sowie ermächtigende bzw. einschränkende Faktoren auf verschiedenen räumlichen Ebenen untersucht. Vorgeschlagen wird eine Typologie von vier Abläufen der regionalen Diversifizierung durch Kreuztabellierung von verwandter im Vergleich zu unverwandter Diversifizierung mit Nischenbildung im Vergleich zu Regimeübernahme; ebenso wird eine Reihe von Vorschlägen entwickelt.

\section{SCHLÜSSELWÖRTER}

evolutionäre Wirtschaftsgeografie; Übergangsstudien; regionale Diversifizierung; unverwandte Diversifizierung; institutionelles Unternehmertum; institutionelle Veränderung

\section{RESUMEN}

Hacia una teoría de la diversificación regional: combinación de ideas de la geografía económica evolutiva y los estudios de transición. Regional Studies. En este artículo desarrollamos un marco teórico de la diversificación regional al combinar las ideas de la geografía económica evolutiva y los estudios de transición. Argumentamos que una teoría de diversificación regional no solo debe construirse sobre el actual concepto de diversificación relacionada sino también teniendo en cuenta los procesos de diversificación inconexa al considerar el papel de las actividades en los procesos de empresariado institucional, así como los factores permisivos y limitantes a diferentes escalas espaciales. Proponemos una tipología de cuatro trayectorias de diversificación regional mediante una tabulación cruzada de diversificación relacionada en comparación con diversificación inconexa y de una creación de nichos frente a la adopción del régimen, y presentamos una serie de propuestas.

\section{PALABRAS CLAVES}

geografía económica evolutiva; estudios de transición; diversificación regional; diversificación inconexa; empresariado institucional; cambio institucional

JEL B15, O33, R11, R58

HISTORY Received 27 June 2016; in revised form 26 October 2016

\section{INTRODUCTION}

In recent times, scholars in economic geography have been preoccupied with the question how regions diversify into new industries (Neffke, Henning, \& Boschma, 2011) and new technologies (Rigby, 2015), how regions develop new growth paths (Isaksen \& Trippl, 2014; Martin, 2010), and why regions differ in their ability to do so (Boschma \& Capone, 2015). Most empirical studies have focused on the process of related diversification and regional branching, and have shown that related diversification is the rule, while unrelated diversification is the exception (Boschma, 2016). Though regions display a clear tendency to diversity into related activities, some have argued that unrelated diversification is nevertheless important to secure longterm economic development, as the process of related diversification might eventually come to a halt due to a lock-in (Saviotti \& Frenken, 2008). Hence, attention for related diversification should go hand in hand with attention for unrelated diversification.

Unrelated diversification is expected to stem from breakthroughs that emerge from recombining previously unconnected technologies into a new configuration (Castaldi, Frenken, \& Los, 2015; Fleming, 2001). Such true Schumpeterian 'Neue Kombinationen', if successful, may provide a long-term source of competitiveness as other regions that do not share the same specialized capabilities being recombined will find it hard to copy such a success. Such a policy strategy can be combined with an explicit aim to address persistent societal challenges such as climate change, ageing, internet crime and youth unemployment (Coenen, Hansen, \& Rekers, 2015). Hence, new solutions might be, to a considerable extent, unrelated to existing technologies as well as to institutions. 
While some scholars have started working on the topic of unrelated diversification using both case studies (Binz, Truffer, \& Coenen, 2016; Dawley, MacKinnon, Cumbers, \& Pike, 2015) and statistical approaches (Boschma \& Capone, 2015; Neffke, Hartog, Boschma, \& Henning, 2014), insights from these studies have remained fragmented at best. The objective of this paper is to make a first step in filling this gap. In doing so, the role of agency in the current Evolutionary Economic Geography (EEG) framework on regional diversification will have to be better theorized (Neffke et al., 2014). Furthermore, as the prime focus has been on the enabling conditions embodied in related capabilities, too little emphasis has been on constraining factors embodied in vested interests. Such constraints stem from interests solidified into institutions at both the regional level (as embodied in policies, laws and regulations, but also cultures, policy styles and labour markets) and the global level (socio-technical regimes). A theory of regional diversification has therefore explicitly to address agency who purposefully strives to overcome constraints to diversification.

The transition literature provides inroads to address these issues (Bergek, Jacobsson, Carlsson, Lindmark, \& Rickne, 2008; Geels, 2002; Rip \& Kemp, 1998). Radical novelty is understood to depend on experimental alignment process of heterogeneous social and technical elements into new socio-technical configurations. In this perspective, actors are essentially forced to adopt a bricolage mode of innovation while having to cope with vested interests and technological and cognitive lock-ins within established socio-technical regimes. As a consequence, the focus is more on experimentation and how institutional entrepreneurship leads to institutional change (Coenen \& Truffer, 2012). Whereas several economic geographers have criticized the limited attention in EEG to agency and institutions in processes of regional diversification (Boschma \& Capone, 2015; Coe, 2011; Coenen, Asheim, Bugge, \& Herstad, 2016; Hassink, Klaerding, \& Marques, 2014; Kogler, 2015; MacKinnon, Cumbers, Pike, Birch, \& McMaster, 2009; Neffke et al., 2014), few have made explicit theoretical suggestions how such limitations can be overcome. This motivated the authors to enrich EEG with insights from the transition literature, which shares evolutionary foundations with EEG, but rather focuses on the interplay between incremental versus disruptive processes of interrelated industrial, institutional and technological change. Hence, it offers a complementary perspective on regional diversification beyond aggregated firm-driven diversification, yet couched in evolutionary terminology (Truffer \& Coenen, 2012).

This paper builds on both EEG and the transition literatures to develop a theoretical framework on regional diversification. Proposed is a theory of regional diversification that emphasizes agency in the processes of institutional entrepreneurship that underlie regional diversification, as well as the enabling and constraining factors at various spatial scales. From this, one can derive the buildings blocks of a theory of both related and unrelated diversification.
The paper is structured as follows. The second section discusses the EEG literature on regional diversification. Despite a few attempts, it is argued that a comprehensive theoretical framework on regional diversification in regions is still underdeveloped. The third section discusses elements from the transition literature that address a number of weaknesses in EEG in this respect. The fourth section presents the main features of the proposed theoretical framework on regional diversification. The fifth section concludes.

\section{EVOLUTIONARY ECONOMIC GEOGRAPHY (EEG) AND REGIONAL DIVERSIFICATION}

There is a rapidly growing interest in the question how regions develop new growth paths, and why regions differ in their ability to do so (Boschma \& Frenken, 2006). The recent EEG literature on regional diversification looks at the presence of locally related activities as an enabling factor. Studies show that existing local capabilities condition which new activities are more likely to develop in regions (Berge \& Weterings, 2014; Boschma, Balland, \& Kogler, 2015; Boschma, Heimeriks, \& Balland, 2014; Boschma, Minondo, \& Navarro, 2013; Colombelli, Krafft, \& Quatraro, 2014; Essleztbichler, 2015; Feldman, Kogler, \& Rigby, 2015; Heimeriks \& Balland, 2015; Kogler, Rigby, \& Tucker, 2013; Neffke et al., 2011; Quatraro \& Montresor, 2015; Rigby, 2015; Tanner, 2014, 2016) and countries (Bahar, Hausmann, \& Hidalgo, 2014; Boschma \& Capone, 2015; Hidalgo, Klinger, Barabasi, $\&$ Hausmann, 2007). These studies conclude that relatedness is an important driver of regional diversification, despite the fact that studies employ different dependent variables (like new products, industries, technologies), relatedness measures (e.g., product relatedness, technological relatedness, skill relatedness, input-output relatedness), spatial units of analysis (countries, regions, cities, labour market areas) and time periods (Boschma, 2016). So, related diversification is found to be a more common phenomenon in regions, but unrelated diversification also occurs, though more rarely.

From an evolutionary point of view, the finding that related diversification is much more common than unrelated diversification does not come as a surprise. Diversification in regions is a deeply uncertain process that can be reduced by relying on existing local capabilities when diversifying into new activities (Boschma \& Frenken, 2011; Frenken, van Oort, \& Verburg, 2007). For instance, it is less problematic for regions to move from motor cycles to trucks than from bananas to computers, as motor cycles and trucks require similar capabilities while bananas and computers require very different capabilities. Unrelated diversification occurs when a region develops a new activity that requires very different capabilities than existing local activities and, hence, tends to be driven by actors who built up their capabilities elsewhere (migrants, multinationals) and, in some cases, were supported by state policies (Dawley et al., 2015; Neffke et al., 2014). Alternatively, unrelated diversification may stem from within the region 
by recombining previously unconnected technologies leading to 'Neue Kombinationen' (Castaldi et al., 2015).

There is some research on enabling conditions for unrelated diversification. Xiao, Boschma, and Andersson (2016) showed that more knowledge-intensive regions in Europe are more likely to move in more unrelated activities, as compared with more knowledge-extensive regions in the European periphery. Other scholars are exploring the role of national institutions on related versus unrelated diversification. Boschma and Capone (2015) found that liberal market institutions (as compared with coordinated market institutions) favour more unrelated diversification at the country level. Cortinovis, Xiao, Boschma, and Van Oort (2016) did not find an effect of regional formal and informal institutions on the tendency of regions to diversify in related or unrelated activities. Scholars have also suggested that bridging networks and non-proximate links would favour unrelated diversification, but systematic evidence is still lacking (Crespo, Suire, \& Vicente, 2014). In sum, this emerging literature on unrelated diversification is still fragmented and underdeveloped, often singling out one factor, and not providing a comprehensive theoretical framework.

A more fundamental limitation of the regional diversification literature has been its primary focus on the role of regional capabilities, without taking account of the role of agency at the micro-level (Boschma, 2016). In the late 1980s, the window of locational opportunity (WLO) approach made an early attempt to link human agency to new industry formation in place (Scott \& Storper, 1987; Storper \& Walker, 1989). This was regarded crucial when it is impossible for new industries to build on locally available capabilities. In that case, new industrial activities create their own economic and institutional conditions of support in place as to build regional capabilities, networks and regulations, or attract them from other places. In that sense, a favourable environment is more likely the result of, rather than a precondition for, such an emergent process. This does not imply that local capabilities do not play a role: some new industries rely more heavily on local generic resources than other industries (Boschma, 1997), but the emphasis in the WLO approach is clearly on the emergence process through which new industries create a conducive milieu, instead of the other way around. However, this WLO approach remained largely conceptual: it has not been subject to any systematic empirical research, nor did it specify in detail how and by whom institutional change comes about.

A key impulse to the development of a micro-perspective on regional diversification was given by Klepper in the 2000s. He considered the role of agency as crucial for the study of new industry formation by looking at the importance of individuals (spinoff entrepreneurs) and firms (diversifiers) that make regions diversify (Buenstorf \& Klepper, 2009; Klepper, 2007). Klepper contributed to an agency-based explanation of regional diversification by focusing mainly on entrepreneurs spinning from and incumbents diversifying from related activities. His agency-based perspective was focused entirely on firms, not on other types of actors that affect the tendency of regions to diversify in new activities. Klepper's theory also paid little attention to the local environment as conditioning factor, and how actors actively shape their local environment.

In sum, what is still underdeveloped in EEG is a comprehensive theory on related and unrelated diversification in regions that (1) incorporates the role of human agency and their engagement with processes of institutional entrepreneurship in particular; (2) gives a full account of the role of constraining factors, ${ }^{1}$ besides enabling factors, as the diversification process in regions is often contested by vested interests at various spatial levels; (3) moves beyond an exclusive focus on regional or national capabilities to account for influences from the outside; and (4) follows a co-evolutionary perspective in which regional diversification is conceptualized as a process based on the dynamic interplay between agency and its changing technological, institutional and spatial context.

\section{TRANSITION THEORY: BRICOLAGE, SYSTEMIC ALIGNMENT AND NICHE SCALING}

In this quest for a more comprehensive theory of regional diversification, it is argued that the transition literature provides useful and complementary concepts and insights. That literature has an explicit account of human agency that relies on concepts like bricolage and institutional entrepreneurship. Moreover, it proposes a meso-level account of diversification, as embodied in the creation of niches through systemic alignment that is attentive to both constraining and enabling factors internal and external to a region, and it addresses how niches for experimentation are mindfully created and scaled in the context of regimes through co-evolutionary processes of shielding, nurturing and empowerment. These topics are discussed below.

\section{Bricolage as a core mechanism in unrelated diversification}

In order to explain unrelated diversification, the analysis is broadened so one can ask how other resources, strategies and actors get mobilized to interrelate proximate and distant knowledge stocks in the generation of novelty. A well-known study on unrelated diversification 'avant la lettre' was presented by Garud and Karnøe (2003), contrasting the emergence of the wind turbine industry in Denmark and the United States. In EEG terms, they argued that the US pathway represented a typical knowledge intensive (high-tech) strategy trying to optimize for related variety (Frenken et al., 2007), and following a policy approach oriented at technological breakthrough narrowly defined. In Denmark, the wind industry developed through a process of trial and error, collaboration and mobilization of various resources (knowledge, financial and institutional) that involved a broad set of local actors. They consisted of firms, farmers, policy-makers, public research 
organizations and non-governmental organizations (NGOs), distributed across a wide spectrum of different (and, in terms of competences, unrelated) industries like mechanical equipment, electronics, farmers and energy utilities. Building on Lévi-Strauss' work on resource scarce innovation processes (Lévi-Strauss, 1967), Garud and Karnøe (2003) called this ideal type mode 'bricolage'. As they show, the Danish bricolage approach that begins with a low-tech design but ramps up progressively prevails over the US high-tech breakthrough approach.

The term 'bricolage' alludes to the consideration of a multiplicity of actors embedded in networks who collectively draw on a broad set of distributed resources such as money, material components, discourses, knowledge, legitimacy and skills, organizational arrangements and political regulation in order to create new industrial pathways through processes of mindful deviation (Baker \& Nelson, 2005; Duymedjian \& Rüling, 2010). The key ability of actors in bricolage is to enable the alignment of a heterogeneous set of actors, institutions and technologies in order to establish socio-technical 'configurations that work' (Callon, 1998; Rip \& Kemp, 1998). Through bricolage, path creation is understood as an iterative construction process where networks of distributed actors jointly create new market segments and user profiles, adapt regulations, lobby for subsidies, or define new technical standards and thereby ultimately create the conducive environment that helps a new industry develop and prosper in a region (Garud \& Karnøe, 2003; Garud, Kumaraswamy, \& Karnøe, 2010). Thus, the notion of bricolage helps to specify further agency processes implicit in the aforementioned work in EEG on windows of locational opportunity (Storper \& Walker, 1989) and firm-based perspectives on regional diversification (Klepper, 2007; Neffke et al., 2014). As a consequence, the generation of unrelated radical novelty is likely to be a messy, step-wise and experimental process. This requires entrepreneurship not only to be proficient in the relevant knowledge fields but also to be capable of embedding new ideas in a wider institutional environment. This is exactly what Hughes (1993) identified as 'system builders' being a crucial factor in the emergence of infrastructure sectors like electricity in the early 20th century.

The bricolage approach became very prominent in organization and management studies (Baker, Miner, Dale, \& Eesley, 2003; Stinchfield, Nelson, \& Wood, 2013). It has arguably been less developed for regional development and policy processes. Nonetheless, drawing on the work of Sabel (1996), previous research on EU regional innovation strategies has conceptualized these as 'regional experimentalism' in which:

the state, firms and intermediaries work in small-scale repeated interactions in an attempt to (re)define regional development support services and priorities in a collective manner, establish specific targets and responsibilities and monitor outcomes in a way that facilitates learning on the part of those in a position to respond.

(Henderson, 2000, p. 349; cf. Morgan \& Henderson, 2002)
Similarly, albeit 15 years later, experimentalism and entrepreneurial discovery are emphasized in the policy framework of smart specialization (Foray, David, \& Hall, 2009; Foray, David, \& Hall, 2011). Here, the ability is crucial to combine and relate knowledge about science, technology and engineering with knowledge of market growth potential, potential competitors as well as the whole set of inputs and services required for launching a new activity.

What is highlighted in smart specialization, albeit somewhat implicitly, is that entrepreneurship is not just about 'taking a technology to the market' (Sotarauta \& Pulkkinen, 2011). While traditionally entrepreneurship is considered key for experimentation in combinatorial knowledge dynamics for related diversification (Frenken \& Boschma, 2007), what is equally emphasized through the notion of bricolage is the need for institutional entrepreneurship. Here, actors break with existing institutionalized rules and practices associated with the dominant institutional logics (see the concept of regime below) and institutionalize the alternative rules, practices or logics they are championing (Battilana, 2006; Garud, Hardy, \& Maguire, 2007). Institutional entrepreneurs are typically heterogeneous actors including, but not limited to, firms or individual entrepreneurs who mobilize resources, competences and power to create new or transform existing institutions (Battilana, Leca, \& Boxenbaum, 2009; Sotarauta \& Pulkkinen, 2011).

In order to unpack how bricolage, experimentation and institutional entrepreneurship may give rise to new sociotechnical pathways, the recent literature on socio-technical transitions proves to provide a number of relevant insights.

\section{The initiation of new pathways through socio- technical alignment}

Transition Studies represent a scholarly field that has emphasized the role of distributed agency in the development of new industries and the crucial role of socio-technical alignment. Its key focus concerns transformative shifts in systems of production and consumption that unfold as disruptive technological change co-evolves with changes in markets, user practices, policy, discourses and governing institutions (Geels, 2002; Kemp, Schot, \& Hoogma, 1998; Markard, Raven, \& Truffer, 2012; Rip \& Kemp, 1998). Empirically, this literature has been primarily interested in understanding and explaining historical examples of long-term yet disruptive technological change such as the transition from sailing to steam ships (Geels, 2002). Furthermore, this literature is well known for its engagement in understanding and contributing to the more normative objective of radically improving societal systems of provision in order to comply with conditions of sustainability in, for example, energy, mobility, water, housing and food (Frantzeskaki, Castan-Broto, Coenen, \& Loorbach, 2016; Fuenfschilling \& Truffer, 2014; Geels, Kemp, Dudley, \& Lyons, 2012; Grin, Rotmans, \& Schot, 2011; Spaargaren, Oosterveer, \& Loeber, 2012; Verbong \& Geels, 2012). 
Transition Studies emerged out of an evolutionary economics (Nelson \& Winter, 1982) and a social-constructivist understanding of innovation processes (Rip \& Kemp, 1998), emphasizing that successful socio-technical configurations have to be actively constructed and stabilized. Drawing furthermore on the Schumpeterian notion of creative destruction, research on socio-technical transitions is specifically concerned with the role of emergent technologies that challenge and struggle against incumbent actors who dominate a particular sector (Bergek et al., 2015; Markard et al., 2012). In analyzing this process, transitions research is heavily influenced by the concept of path dependency. Building on an earlier conceptualization of technological trajectories and regimes (Dosi, 1982; Nelson \& Winter, 1977), as well as sociological insights on agency and structure (Giddens, 1984), the concept of the sociotechnical regime accounts for the persistence and rigidity of structures within a system (Fuenfschilling \& Truffer, 2014). It is defined as the 'coherent complex of scientific knowledge, engineering practices, production process technologies, product characteristics, skills and procedures, established user needs, regulatory requirements, institutions and infrastructures' (Rip \& Kemp, 1998, p. 338). The 'structuration' of this complex, in terms of its internal alignment, is high, providing stable rules and coordinating effects on actors. As a consequence, sectors that have a strong regime are considered as hostile selection environments for disruptive innovations and radical (technological) change. Instead they are prone to lock-in and path dependency and largely geared to generate incremental innovations and gradual change.

Here, Transition Studies provides useful insights. Even though it emphasizes how (radical) novelty is constrained and contested by a regime, it specifies at the same time how such radical novelty emerges. This is mostly conceptualized through the notion of niches (Geels \& Raven, 2006) or through work done in the field of technological innovation systems dealing with emergent (sustainable) technologies and industries (Bergek et al., 2008; Hekkert, Suurs, Negro, Kuhlmann, \& Smits, 2007). Similar to previous work on bricolage and path creation (Garud et al., 2010; Karnøe \& Garud, 2012; Sydow, Windeler, Müller-Seitz, \& Lange, 2012), it subscribes to the notion that new paths do not emerge from external shocks but from the strategic agency in heterogeneous actor groups that jointly act upon locked-in structures and mobilize resources to create a new industry (Simmie, 2012).

Due to its strong focus on socio-technical alignment, Transition Studies have been, until recently, rather silent about the spatial structure and preconditions for these processes. Truffer and Coenen (2012) proposed three conceptual platforms where Transition Studies could address this shortcoming by engaging with the regional studies and economic geography literature: (1) emphasizing the local embedding of new industries and technologies by an integrated view on the joint alignment of socio-technical and socio-spatial structures; (2) the consideration of multi-scalar factors of transitions like trans-regional actors networks and institutions; and (3) an attentiveness to power relationships in these processes. Since these early proposals, a sizable number of studies have emerged which further elaborated the geography of transitions field (Hansen \& Coenen, 2015; Murphy, 2015; Truffer, Murphy, \& Raven, 2015). A recent review (Hansen \& Coenen, 2015) has shown that the large majority of case studies dealing with the geography of transitions has zoomed in on the importance of place dependence for transition processes. This has helped to specify that niche formation in emergent clean technologies is contingent on place-specific factors such as local related variety, local natural resource endowments, local market formation, urban and regional visions and policies, and local informal institutions. While a higher level of sensitivity concerning the importance of place dependence is gained in these studies, it may have come with a bias towards emphasizing particularities found in single-case studies of distinct places. Another insight of this work holds that regimes, even though they can be considered as global structures, these may nevertheless exhibit a high degree of local variation (Späth \& Rohracher, 2012). And niches, on the other hand, are not bound to the local scale, but often consist of globally interconnected sets of activities (Binz, Truffer, \& Coenen, 2014; Quitzow, 2015; Sengers \& Raven, 2015).

Proposing a more systematic framework regarding unrelated diversification, Binz, Harris-Lovett, Kiparsky, Sedlak, and Truffer (2016) suggested how the emergence of new industrial pathways in regions can be framed as a process of bricolage by mobilizing and aligning different resources, like knowledge, markets, investment and legitimacy. Rather than assuming that markets for new industrial pathways pre-exist, it treats (niche) markets as a resource for radically new technologies, products and services that have to be actively created through, for example, lobbying, regulation and standardization (Dewald \& Truffer, 2012). Similarly, financial investment requires active mobilization through networking between entrepreneurs, investors and intermediary organization. Legitimacy, finally, is emphasized as a key resource for new industry formation as new products and processes are often not aligned with existing regulative, normative and cognitive institutions resulting in initial scepticism and lack of user acceptance (Aldrich \& Fiol, 1994; Binz, Harris-Lovett, et al., 2016; Yeung \& Coe, 2015). Therefore, actors promoting unrelated diversification have to engage in considerable institutional work either to adapt the industry to existing institutional structures or to adapt these structures to match the industry's needs better (Bergek et al., 2008; Fuenfschilling \& Truffer, 2016). Drawing on a case study of industry formation for on-site water recycling in Beijing, Binz, Harris-Lovett, et al. (2016) found that such processes of resource mobilization and alignment are not confined to local interactions but depend on a complex interplay between local and global configurations.

\section{Establishing pathways by scaling of niches}

While the notion of bricolage, on the one hand, broadens the set of resources considered for new path creation, it 
also stresses the highly experimental nature of new path creation. Interestingly, experimentation is mentioned by Martin (2010) as a critical process for new path creation in regions, but this is not further elaborated. In contrast, research in Transition Studies has foregrounded the role of experimentation, particularly in connection to the concept of niches which are conceived as 'incubation spaces' for radically new technologies and/or practices characterized by high technological, institutional and market uncertainty. Such niches protect radical innovations against market selection and institutional pressures from a regime and allow actors to learn about these novelties and their uses through experimentation (Coenen, Raven, \& Verbong, 2010; Geels, 2002). When niches gather sufficient momentum so that these relatively loose configurations become institutionalized they create capacity for emergent technologies and practices to challenge and substitute a regime and induce transitions.

In the transition literature, strategic niche management elaborates how heterogeneous experiments can be managed in order to support socio-technical alignment (Hoogma, Kemp, Schot, \& Truffer, 2002; Schot \& Geels, 2008). Three processes are distinguished for successful development of a niche: shielding, nurturing and empowerment (Smith \& Raven, 2012). All three processes essentially enable different actors to try out new alignments between institutions, technologies and actors. Shielding refers to those activities that hold at bay selection pressures from a regime and that afford the protective space for path-breaking innovations to emerge. Nurturing refers to those activities that then support the development of path-breaking innovation (Schot \& Geels, 2008) such as the processes of anchoring elaborated by Binz, Harris-Lovett, et al. (2016).

Experimental projects in real-life contexts are seen to be critical by bringing together actors from variation and selection environments in shared networking and learning activities. In these experiments, firms, research institutes, universities and governments search and explore the best possible combinations of innovations and their social and institutional embedding (Bulkeley \& Castán Broto, 2013). A key challenge that these niche experiments are facing concerns how to upscale successful innovations and practices beyond their initial niche (Geels, Hekkert, \& Jacobsson, 2008). Whereas initial attention has been paid primarily to the roles of 'shielding' and 'nurturing', Smith and Raven (2012, p. 1034) argue that more focus should be given to the 'empowering' role of niches, which 'involves processes that make niche innovations competitive within unchanged selection environments (fit and conform) or processes that change mainstream selection environments favourable to the path-breaking innovation (stretch and transform)'.

Summing up, it is suggested here that Transition Studies provide a suitable framework for analyzing processes of unrelated diversification in particular. In unrelated diversification, agency in the form of bricolage, institutional entrepreneurship or policy action comes more heavily to bear and successful attempts rely on experimental activities, strategies of resourceful actors, capabilities of 'system building' and partly also serendipity (Dawley, 2014; Dawley et al., 2015). Transition Studies have so far been less strong in formulating hypotheses about which individual actors, technologies, networks or institutions are more amenable to successful path creation. What the literature suggests, however, is to be attentive of which constellations of factors might be more or less amenable for conducting successful bricolage processes. Moreover, the transition literature has only started to look at the geography of niches and regimes, and what are the implications for (related and unrelated) diversification in regions. It is argued that regimes tend to be global as they depict a structural pattern of alignment between actors, institutions and technologies that has reached validity beyond specific territorial contexts and which is diffused through international networks (Fuenfschilling \& Binz, 2016) though not equally present and institutionalized in all regions (Späth \& Rohracher, 2012). A similar ambivalence may be found for the geography of niches which might emerge regionally, though often in parallel with global networks connecting them (Sengers \& Raven, 2015).

\section{TOWARDS A THEORY OF REGIONAL DIVERSIFICATION}

In the foregoing, it has become clear that scholars in EEG and Transition Studies have a common interest to understand the nature, loci and radicalness of novelty. However, their perspectives, namely units of analysis, are different. In EEG, the notion of novelty is spatially defined and treated: looking from the perspective of a region, scholars distinguish between related and unrelated diversification. The more a new industry is unrelated to the capability base already built up in the region, the more a new industry marks a radical departure from a region's own past. The transition perspective, by contrast, looks at the construction of niches that challenge an existing sociotechnical regime that is globally dominant in a particular sector. Here, the radicalness lies in the extent to which the niche differs from the globally institutionalized regime.

The notions of unrelated diversification and niche creation, thus, should not be confused. Unrelated diversification is defined with reference to a particular region with certain capabilities ('place'), while a new niche is defined with reference to a particular regime following a certain technological trajectory ('path'). Put differently, place and path dependence are two distinct dependencies in evolutionary processes (Heimeriks \& Boschma, 2014; Martin \& Sunley, 2006). Place dependence stems from the local reproduction of localized knowledge, territorial institutions and vested interests embedded in places, which tends to hamper processes of unrelated diversification of a regional economy. Path dependence stems from shared cognitive frames, standards and institutions embedded in global socio-technical regimes, which tends to hamper the development of new niches and their further development into alternative socio-technical regimes. So, place and path 
dependence relate to socio-spatial and socio-technical embedding respectively (Truffer \& Coenen, 2012).

Though distinct, place and path dependence typically reinforce each other. A regime tends to be globally organized and hence present in many regions. In regions where a regime is both dominant and strongly aligned with localized knowledge, territorial institutions and vested interests, a change of regime will be very unlikely, as niche actors will have to deviate from their socio-spatial and socio-technical embedding. Having said this, regimes are neither monolithic nor fully globalized (Fuenfschilling \& Binz, 2016; Späth \& Rohracher, 2012). A regime may be strong in some regions and weaker in other. That is, regions differ in the extent to which a regime is adopted and the degree to which the regime is regionally institutionalized (Crouch \& Voelzkow, 2009). Moreover, in some regions, a sector can be dominated by a single regime, while in other regions this sector may be characterized by co-existing regimes. Think, for example, of cities dominated by cars versus cities where cars, bikes and public transport co-exist and may be even made complementary. Hence, one can expect windows of opportunity to exist in regions where the regime is less dominant and only weakly institutionalized or hybridized.

The distinction between place and path dependence thus implies that the two processes of unrelated diversification at the regional level and niche creation at the sectoral level do not necessarily coincide. This is what is depicted in Table 1, where radicalness is distinguished along both the regional dimension (related versus unrelated) and the sectoral dimension (regime versus niche). Thus, in the case of regional diversification, a new industry is new to the region, while in the case of a niche creation it is new to the world. A region creating a new niche may do so via unrelated or related diversification. For example, Danish regions specialized in agriculture diversified into an unrelated niche of wind turbine production. An example of related diversification leading to a new niche would be Silicon Valley specialized in the information and communication technology industry currently creating a niche for self-driving cars. In both examples, a new-to-the-world niche was created through regional diversification.

The same possibilities of related and unrelated diversification hold when a region becomes active in an existing regime technology. That is, a region may diversify by entering a global regime through related or unrelated diversification. For example, it may diversify in a related manner from operating in the oil regime serving the transport sector into the (fossils-based) plastics regime serving the packaging industry. However, a region may also enter a regime that is unrelated to the capabilities already present in the region,

Table 1. Typology of regional diversification.

\begin{tabular}{llll}
\hline & \multicolumn{2}{c}{ REGION } \\
\cline { 3 - 4 } & & RELATED & \multicolumn{1}{c}{ UNRELATED } \\
\hline SECTOR & REGIME & Replication & Transplantation \\
& NICHE & Exaptation & Saltation \\
\hline
\end{tabular}

like a desert region specialized in tourism that discovers oil and enters the oil regime. For each new industry created in a region, one can thus assess whether the industry is related or unrelated to the region's existing capability base and whether the industry is constituting a new niche in a particular sector, or whether it extends an already existing regime in a sector.

One can thus derive a typology of four different regional diversification processes. For each of the four diversification trajectories, the type and extent of institutional work involved, the expected driving actors and the spatial logics are further theorized below, as summarized in Table 2.

Replication stands for the most conservative diversification logic in which a region develops related industries by adopting a technology that is institutionalized in a global socio-technical regime. From the regime perspective, the process of replication entails the gradual process by which a regime diffuses at a global scale. Hence, the notion of replication follows from the theory of Winter and Szulanski (2001) about routine replication by organizations across regional contexts. In this diversification logic, a region replicates largely its existing capability base by branching out into related activities and at the same time largely replicates existing knowledge, institutions and interests embedded in an existing socio-technical regime. This strategy can be very successful since the region can become readily competitive in an existing global regime as it can leverage its experience in related industries (Boschma \& Frenken, 2011).

Transplantation stands for a diversification trajectory in which a region develops an industry unrelated to its knowledge base and institutions, yet based on adopting a regime technology from the global system. The use here of the term 'transplantation' is in line with Martin and Sunley (2006), who mention transplantation as a primary mechanism of creating a 'new pathway of regional growth', while it also builds on the notion of institutional transplantation of policy institutions across countries (De Jong, Lalenis, \& Mamadouh, 2002). This diversification logic is a more risky one as a region cannot build on its existing knowledge base and regional institutions while it has to compete with many other regions where the regime is already present. Hence, this strategy can only be successful if resources other than knowledge and institutions can be leveraged, such as location, connectivity, a critical natural resource or low labour costs. The latter two conditions are often present in developing countries, where regional and national governments follow a catch-up strategy through imitation of established technologies, that is, by diversifying into regimes that are unrelated to their pre-existing capability base.

Exaptation refers to a diversification logic where new applications are discovered for existing knowledge or technology (Dew, Sarasvathy, \& Venkataraman, 2004). Innovation by exaptation has received considerable interest lately (Andriani \& Cattani, 2016; Andriani \& Cohen, 2013), and from various perspectives including psychology of perception (Felin, Kauffman, Mastrogiorgio, \& Mastrogiorgio, 2016), niche construction theory (Dew \& Sarasvathy, 2016) and a narrative approach (Garud, Gehman, \& Giuliani, 2016). The canonical example of 
Table 2. Characteristics of diversification trajectories.

\begin{tabular}{|c|c|c|c|c|c|c|}
\hline Process & Relatedness & Level & Risk & Institutional work & Key actors & Spatial logic \\
\hline Replication & Related & Regime & Low & Maintenance & Regional incumbents & Localized \\
\hline Transplantation & Unrelated & Regime & Moderate & $\begin{array}{l}\text { Creation (especially } \\
\text { regionally) }\end{array}$ & $\begin{array}{l}\text { Regime incumbents/ } \\
\text { governments }\end{array}$ & $\begin{array}{l}\text { Global to } \\
\text { regional }\end{array}$ \\
\hline Exaptation & Related & Niche & Moderate & $\begin{array}{l}\text { Creation (especially } \\
\text { globally) }\end{array}$ & New entrants & $\begin{array}{l}\text { Regional to } \\
\text { global }\end{array}$ \\
\hline Saltation & Unrelated & Niche & High & Creation (all levels) & Broad range & $\begin{array}{l}\text { Global to } \\
\text { global }\end{array}$ \\
\hline
\end{tabular}

exaptation in biology is bird wings that initially evolved for insulation purposes but later developed into a means to fly. Similarly, many technologies find applications that were not foreseen when first developed. For example, technologies like the laser, the computer and plastics have continued to find new applications in very diverse sectors. Exaptation thus refers to a diversification logic where a region builds on an existing knowledge base and succeeds in entering many sectors by creating new niches. Silicon Valley and its ICT knowledge base is a perfect example, branching out in many sectors by developing new niche technologies with some of these successfully growing out into a new global regime (personal computers, online advertising, mobile telephony), while other (still) having a niche status (self-driving cars, home-sharing platforms, smart homes).

Finally, saltation (or leap) can lead to regional diversification. Saltation is a term used in biology to denote the process in which just a single mutation ('macro-mutation') can lead to speciation. In the context of our framework, the concept of saltation leading to a new niche would refer to an innovation that is not only new to the region but also new to the world. An example is the discovery of penicillin by Alexander Fleming in 1928 in London, which later became mass-produced in the United States to support Allied forces during the Second World War; another is Thomas Edison's light bulb and the subsequent rise of the New Jersey lamp industry (Smil, 2006). Even if the saltation idea in biology is contested and not widely accepted, the idea that a single innovation can sometimes lead to a whole new industry is widespread in innovation theory. In this context, scholars often speak of breakthrough innovations that differ in a fundamental sense from previous technologies and provide the basis for many incremental improvement later on (Ahuja \& Lampert, 2001). In this context, some explicitly refer to the distinction between micro- and macro-mutations in biology, and speak analogously of micro- and macro-inventions in technological development (Mokyr, 1990). Related to the notion of saltation is the distinction between competence-enhancing and competence-destroying innovation (Anderson \& Tushman, 1990), where the latter notion is in line with saltation as it highlights the radical departure from existing capabilities.

Going back to the agency perspective advocated by organization scholars and their theories of bricolage (Garud \& Karnøe, 2003) and institutional entrepreneurship
(Battilana et al., 2009), one can further specify the role of actors in the four diversification trajectories. Clearly, in the case of replication, actors operate in a context where they can build on (related) existing regional strengths and global regimes. The institutional work required, then, is one of maintaining existing institutions (Fuenfschilling \& Truffer, 2014). These patterns are readily explained by the key notions of place and path dependence, respectively. In particular, one expects regional industry incumbents to be most active in this process, since related diversification into established regimes fits most firms' own strategy to grow and expand (Klepper, 2002; Neffke et al., 2014). Another reason why one expects large incumbent firms to be the typical actor in this process is that regime entry requires many resources and a long-term vision given the entry barriers in established regimes.

In the case of transplantation, institutional work has to be done at the regional level to adapt institutions such that globally accepted technologies, standards and regulations are accepted and implemented. One can expect that transplantation activities are guided regional and national government as an explicit development strategy, and to are carried out by actors who have both the capabilities and the interests to make the regime diffuse (i.e., regime incumbents), for example, global consultancies, multinational corporations and transnational government agencies. Given that vested interests in a region may well be threatened by the transplantation of regime technology by globally operating regime actors, conflicts may well arise. The introduction of a regime technology that is new to the region often leads to competition for scarce public and private resources. In this context, one can thus regard the regime incumbents as the institutional actor 'mindfully deviating' from regional institutions, and trying to mould them into global regime standards. Such changes will be more readily accepted if a sense of urgency to change exist (e.g., during a severe crisis) (De Jong et al., 2002), opening up windows for institutional entrepreneurship at the regional level (Battilana et al., 2009). Furthermore, one can expect transplantation to be more successful if the institutional distance between actors in the adopting region and in the global regime is small (De Jong et al., 2002; Gertler, 2004). In sum, transplantation is certainly actor led, and a key question holds in what contexts what actor(s) take up this role, how outcomes vary according to the actor(s) taking up this role, and what roles regional governments can play to resolve such conflicts. 
Compared with transplantation, exaptation is much more a local process even if, as explained above, niche creation may well involve concurrent and networked processes across multiple regions. Here, the actors are expected to come from related industries in the region, as exaptation is a process of related diversification. Typically new entrants such as spinoffs, and to a lesser extent diversifying firms, are crucial to pioneer the formation of new industries that build on established ones (Klepper, 2007). The institutional work to be carried out is to get the new niche technology accepted through new regulations and social norms. Regime actors, either regional or global, tend to de-legitimize such efforts and to close windows for such institutional entrepreneurship. Hence, building on the theory of institutional entrepreneurship (Battilana et al., 2009), one expects that attempts to promote new niches by changing regime institutions to be most successful in regions where the regime is not well established or otherwise under pressure due to wider 'landscape pressures', as well as in regions where powerful regime actors are absent and powerful niche actors reside with global reach so as to get a niche globally aligned and legitimized. Regional governments can play this role as well by lobbying for the creation of supporting institutions at national and global levels.

Finally, a new niche created by saltation will be mostly driven by individual heterogeneous agents. Given that such leaps imply that the new path is both unrelated to a region's capabilities and challenging an existing global regime, agents have to deviate at two levels, from path dependence and place dependence. They not only break with established knowledge base and institutions and interests at the regional level, but also have to establish a niche in a global regime. While in transplantation and exaptation, either the regime or the region provide a supporting institutional structure, saltation requires a fundamental change of institutions in both dimensions, that is, both globally at the sectoral level and locally at the regional level. Here, one expects novelty to emerge in a distributed and rather unruly manner, with many heterogeneous agents involved and often located in different regions. As there are only few supporting structures at the regional or global level to build on, these actors have to engage in a collective alignment process emphasized by the notions of bricolage and collective institutional entrepreneurship, for example, as driven by a social movement (Sine \& Lee, 2009).

\section{CONCLUSIONS}

This paper proposes a new typology of regional diversification that combines complementary logics from two different literatures that evolved in parallel, that is, the EEG literature on regional diversification and the transition literature on niche-regime interactions. In doing so, it has been able to tackle a number of weaknesses in both literatures as far as their view on diversification processes is concerned.

The EEG literature on regional diversification has revealed important insights into how regions diversify over time: its main research interest is to understand how regional capabilities enable diversification of regions. Its prime focus has been on related diversification in regions, and less so on unrelated diversification. However, the role of human agency (especially institutional entrepreneurs) has been poorly integrated in this EEG framework on regional diversification. The paper has also argued that EEG lacks a systematic focus on constraining factors (for an exception, see Hassink, 2005), neglects issues like power and conflicts stemming from contradictory interests among stakeholders (Boschma \& Frenken, 2009; MacKinnon et al., 2009), and draws little attention to the process of institutional work by institutional entrepreneurs that is required to overcome such constraints (Battilana et al., 2009).

This paper has argued that the transition literature provides key insights on regional diversification. There is more focus on constraints and resistance from actors dominating established sectoral socio-technical regimes. There is also more focus on experimentation and the role of all sorts of actors including governments that enable, or not, niche formation and institutional change. In that sense, the transition literature provides complementary insights to EEG. However, Transition Studies have also been less keen on developing hypotheses about which actors and contexts are more conducive to regional diversification. There is also little systematic empirical evidence on the geographical configurations of niche formation and regimes so far, and its implications for processes of regional diversification.

A key result from this discussion holds that unrelated diversification and niche creation should be understood as distinct, as the units of analysis in EEG and Transition Studies are different. In EEG, the notion of novelty is spatially defined (new to the region). Here, the radicalness involves the extent to which a new activity in a region can or cannot build on existing related capabilities in the region. The transition perspective looks at the construction of niches that challenge an existing regime that is globally dominant in a particular sector. Here, the radicalness lies in the extent to which the niche differs from the globally institutionalized regime, or not. Based on these two dimensions, four types of regional diversification were derived. Related diversification in regions consist of two types: replication (within an existing socio-technical global regime) and exaptation (creating a niche that can grow out into a new global regime). This paper also distinguished between two types of unrelated diversification: transplantation involves a change in the regional capability base but within the boundaries of the existing socio-technical regime, while saltation stands for the most radical type of regional diversification, requiring not only a transformation of regional capabilities but also a complete regime change.

The authors believe this proposed framework opens up a lot of challenging avenues for future research. A first set of questions concerns the geography of diversification. A key question is how the geography of the four types of diversification trajectories would look like. Are there regions that would be good at in all diversification types? To what extent do regions specialize in one of the diversification 
trajectories, and why, and which regions fail to develop any type of diversification? This also confronts one with a methodological challenge if one would want to analyze diversification in a quantitative manner: how to operationalize the two dimensions (related/unrelated and niche/ regime) in our proposed framework. For each new industry in a region, one needs to assess whether the new industry is related or unrelated to the region's capability base, and whether the new industry is constituting a new niche in a particular sector, or whether it extends an existing regime in a sector. Surely, the EEG literature on regional diversification has recently made progress in developing various relatedness measures, but it is still debating how to assess the degree of relatedness between new and existing local activities, and how to connect relatedness to specific capabilities (Boschma, 2016).

Another set of questions concerns the process of diversification and the role of various actors, such as firms, NGOs, citizen movements, trade associations and universities (Vallance, 2016). This paper has already theorized for all four types of diversification about the extent of agency required, and the likely agents to take up the role of institutional entrepreneurs. Further questions include what kind of strategies actors employ to carry out the institutional work required, at the regional, national and global levels, what types of conflicts can emerge, and how these may differ between the four types of regional diversification (replication, transplantation, exaptation and saltation)? Even in the extreme case of replication where new activities are related to capabilities and institutions at both regional and global levels, the process of diversification is unlikely to be a conflict-free process. In this particular case, it is highly probable that a new industry will take away resources from local related industries (including capital, skilled labour and public subsidies) because these are highly relevant (related) for the new industry. In the other diversification logics, however, actors will probably deal with other sorts of tensions, especially when the existing regime is seriously challenged. Hence, one expects the dynamics and mechanisms of each of the different diversification trajectories to be quite distinct.

A final set of questions addresses the regional contextual factors that condition the diversification trajectories in certain regions. Building on Battilana et al. (2009), this paper has already discussed the more specific institutional contexts that provide windows for institutional entrepreneurship. In general, regional contexts strongly support replication, and may well be hostile towards alternative, risky types of diversification trajectories. At the same time, in such processes of institutional change the institutional entrepreneurs still remain embedded in wider pre-existing institutions. Hence, one can further ask the question which more generic macro-institutional features favour experimentation and institutional entrepreneurship underlying transplantation, exaptation and saltation, respectively. Can one identify institutional conditions that enable such a culture of experimentation? How do different varieties of capitalism condition the different types of regional diversification processes
(Boschma \& Capone, 2015; Cortinovis et al., 2016)? Are certain regions better at running experiments, while others are better at scaling up? And how important are regionexternal linkages (Asheim \& Isaksen, 2002; Neffke et al., 2014; Trippl, Grillitsch, \& Isaksen, 2015)? And how can one relate strategies in global value chains with diversification strategies of countries and regions?

This brings the discussion to the specific role of public policy. The four different diversification logics will have implications for the design and implementation of public policy. So what could be the role of the state in all diversification types (Dawley et al., 2015; Mazzucato, 2013; Morgan, 2013)? How can one operationalize smart specialization policy in terms of these diversification strategies? And do countries/regions go through different types of diversification strategies, like developing countries may shift from a strategy based on catching-up in existing technological pathways (transplantation) to developing new pathways (like exaptation)? Do diversification strategies based on 'normal' innovations differ from those that are connected to 'grand challenges'? How can regions/countries moderate the strength of socio-technical regimes in order to enable niche experiments to emerge and to scale up? And what about the mix of niche promotion and regime weakening policies at regional, national and global levels? This wealth of questions - of theoretical, empirical and policy nature - suggests a fruitful future for research on regional diversification in the years to come.

\section{DISCLOSURE STATEMENT}

No potential conflict of interest was reported by the authors.

\section{FUNDING}

Ron Boschma and Lars Coenen gratefully acknowledge financial support from the Swedish Research Council [Linnaeus grant number 349200680] and Sweden's Innovation Agency Vinnova [grant agreement number 2010-07370].

\section{NOTE}

1. When paying attention to constraining factors, the EEG literature tends to refer almost exclusively to the specific case of old industrial regions in which different types of lock-in are perceived to prevent them shifting into new activities (Grabher, 1993; Hassink, 2005; Coenen, Moodysson, \& Martin, 2015). An exception is a study on cities active in fashion design (Wenting \& Frenken, 2011).

\section{ORCiD}

Lars Coenen (D) http://orcid.org/0000-0002-5671-3988

Bernhard Truffer (D) http://orcid.org/0000-0002-86350911 


\section{REFERENCES}

Ahuja, G., \& Lampert, C. M. (2001). Entrepreneurship in the large corporation: A longitudinal study of how established firms create breakthrough inventions. Strategic Management Journal, 22, 521543. doi:10.1002/smj.176

Aldrich, H. E., \& Fiol, C. M. (1994). Fools rush in? The institutional context of industry creation. Academy of Management Review, 19, 645-670.

Anderson, P., \& Tushman, M. (1990). Technological discontinuities and dominant designs: A cyclical model of technological change. Administrative Science Quarterly, 35, 604-633.

Andriani, P., \& Cattani, G. (2016). Exaptation as source of creativity, innovation, and diversity: Introduction to the special section. Industrial and Corporate Change, 25, 115-131. doi:10.1093/icc/ dtv053

Andriani, P., \& Cohen, J. (2013). From exaptation to radical niche construction in biological and technological complex systems. Complexity, 18, 7-14. doi:10.1002/cplx.21450

Asheim, B. T., \& Isaksen, A. (2002). Regional innovation systems. The integration of local 'sticky' and global 'ubiquitous' knowledge. Journal of Technology Transfer, 27, 77-86.

Bahar, D., Hausmann, R., \& Hidalgo, C. A. (2014). Neighbors and the evolution of the comparative advantage of nations: Evidence of international knowledge diffusion? Journal of International Economics, 92, 111-123.

Baker, T., Miner, A. S., Dale, B., \& Eesley, T. (2003). Improvising firms: Bricolage, account giving and improvisational competencies in the founding process. Research Policy, 32, 255-276.

Baker, T., \& Nelson, R. E. (2005). Creating something from nothing: Resource construction through entrepreneurial bricolage. Administrative Science Quarterly, 50, 329-366. doi:10.2189/ asqu.2005.50.3.329

Battilana, J. (2006). Agency and institutions: The enabling role of individuals' social position. Organization, 13, 653-676. doi:10. 1177/1350508406067008

Battilana, J., Leca, B., \& Boxenbaum, E. (2009). How actors change institutions: Towards a theory of institutional entrepreneurship. Academy of Management Annals, 3, 65-107.

Berge, M. van den, \& Weterings, A. (2014). Relatedness in eco-technological development in European regions. The Hague: Planbureau voor Leefomgeving.

Bergek, A., Hekkert, M., Jacobsson, S., Markard, J., Sandén, B., \& Truffer, B. (2015). Technological innovation systems in contexts: Conceptualizing contextual structures and interaction dynamics. Environmental Innovation and Societal Transitions, 16, 51-64. doi:10.1016/j.eist.2015.07.003

Bergek, A., Jacobsson, S., Carlsson, B., Lindmark, S., \& Rickne, A. (2008). Analyzing the functional dynamics of technological innovation systems: A scheme of analysis. Research Policy, 37, 407429. doi:10.1016/j.respol.2007.12.003

Binz, C., Harris-Lovett, S., Kiparsky, M., Sedlak, D. L., \& Truffer, B. (2016). The thorny road to technology legitimation. Institutional work for potable water reuse in California. Technological Forecasting and Social Change, 103, 249-263. doi:10.1016/j.techfore.2015.10.005

Binz, C., Truffer, B., \& Coenen, L. (2014). Why space matters in technological innovation systems - Mapping global knowledge dynamics of membrane bioreactor technology. Research Policy, 43, 138-155. doi:10.1016/j.respol.2013.07.002

Binz, C., Truffer, B., \& Coenen, L. (2016). Path creation as a process of resource alignment and anchoring. Industry formation for on-site water recycling in Beijing. Economic Geography, 92, 172-200.

Boschma, R. (1997). New industries and windows of locational opportunity. A long-term analysis of Belgium. Erdkunde, 51, $12-22$.
Boschma, R. (Forthcoming 2016). Relatedness as driver behind regional diversification: A research agenda. Regional Studies. http://dx.doi.org/10.1080/00343404.2016.1254767

Boschma, R., Balland, P.-A., \& Kogler, D. F. (2015). Relatedness and technological change in cities: The rise and fall of technological knowledge in U.S. metropolitan areas from 1981 to 2010. Industrial and Corporate Change, 24, 223-250.

Boschma, R., \& Capone, G. (2015). Institutions and diversification: Related versus unrelated diversification in a varieties of capitalism framework. Research Policy, 44, 1902-1914.

Boschma, R., \& Frenken, K. (2006). Why is economic geography not an evolutionary science? Towards an Evolutionary Economic Geography. Journal of Economic Geography, 6, 273-302. doi:10. 1093/jeg/lbi022

Boschma, R., \& Frenken, K. (2009). Some notes on institutions in Evolutionary Economic Geography. Economic Geography, 85, 151-158. doi:10.1111/j.1944-8287.2009.01018.x

Boschma, R., \& Frenken, K. (2011). Technological relatedness and regional branching. In H. Bathelt, M. P. Feldman \& D. F. Kogler (Eds.), Beyond territory. Dynamic geographies of knowledge creation, diffusion and innovation (pp. 64-81). London: Routledge.

Boschma, R., Heimeriks, G., \& Balland, P.-A. (2014). Scientific knowledge dynamics and relatedness in biotech cities. Research Policy, 43, 107-114. doi:10.1016/j.respol.2013.07.009

Boschma, R., Minondo, A., \& Navarro, M. (2013). The emergence of new industries at the regional level in Spain: A proximity approach based on product-relatedness. Economic Geography, 89, 29-51. doi:10.1111/j.1944-8287.2012.01170.x

Buenstorf, G., \& Klepper, S. (2009). Heritage and agglomeration: The Akron tyre cluster revisited. Economic Journal, 119, 705733. doi:10.1111/j.1468-0297.2009.02216.x

Bulkeley, H., \& Castán Broto, V. (2013). Government by experiment? Global cities and the governing of climate change. Transactions of the Institute of British Geographers, 38, 361-375. doi:10.1111/j.1475-5661.2012.00535.x

Callon, M. (1998). An essay on framing and overflowing: Economic externalities revisited by sociology. In M. Callon (Ed.), The laws of the markets (pp. 244-269). Oxford: Blackwell.

Castaldi, C., Frenken, K., \& Los, B. (2015). Related variety, unrelated variety and technological breakthroughs. An analysis of US state-level patenting. Regional Studies, 49, 767-781.

Coe, N. M. (2011). Geographies of production I: An evolutionary revolution? Progress in Human Geography, 35, 81-91. doi:10. 1177/0309132510364281

Coenen, L., Asheim, B. T., Bugge, M., \& Herstad, S. J. (2016). Advancing regional innovation systems: What does Evolutionary Economic Geography bring to the policy table? Environment and Planning. C, Government and Policy. doi:10. 1177/0263774X16646583

Coenen, L., Hansen, T., \& Rekers, J. V. (2015). Innovation policy for grand challenges. An economic geography perspective. Geography Compass, 9, 483-496. doi:10.1111/gec3.12231

Coenen, L., Moodysson, J., \& Martin, H. (2015). Path renewal in old industrial regions: Possibilities and limitations for regional innovation policy. Regional Studies, 49, 850-865. doi:10.1080/ 00343404.2014 .979321

Coenen, L., Raven, R., \& Verbong, G. (2010). Local niche experimentation in energy transitions: A theoretical and empirical exploration of proximity advantages and disadvantages. Technology in Society, 32, 295-302. doi:10.1016/j.techsoc.2010. 10.006

Coenen, L., \& Truffer, B. (2012). Places and spaces of sustainability transitions: Geographical contributions to an emerging research and policy field. European Planning Studies, 20, 367-374. doi:10.1080/09654313.2012.651802 
Colombelli, A., Krafft, J., \& Quatraro, F. (2014). The emergence of new technology-based sectors in European regions: A proximitybased analysis of nanotechnology. Research Policy, 43, 1681-1696. doi:10.1016/j.respol.2014.07.008

Cortinovis, N., Xiao, J., Boschma, R., \& Van Oort, F. (2016). Quality of government and social capital as drivers of regional diversification in Europe (Papers in Evolutionary Economic Geography No. 16.10). Utrecht: Utrecht University.

Crespo, J., Suire R., \& Vicente J. (2014). Lock-in or lock-out? How structural properties of knowledge networks affect regional resilience. Journal of Economic Geography, 14, 199-219. doi:10.1093/ jeg/lbt006

Crouch, C., \& Voelzkow, H. (2009). Innovation in local economies: Germany in comparative context. Oxford: Oxford University Press.

Dawley, S. (2014). Creating new paths? Offshore wind, policy activism, and peripheral region development. Economic Geography, 90, 91-112. doi:10.1111/ecge.12028

Dawley, S., MacKinnon, D., Cumbers, A., \& Pike, A. (2015). Policy activism and regional path creation: The promotion of offshore wind in North East England and Scotland. Cambridge Journal of Regions, Economy and Society, 8, 257-272. doi:10.1093/cjres/ rsu036

De Jong, M., Lalenis, K., \& Mamadouh, V. D. (Eds.) (2002). The theory and practice of institutional transplantation. Dordrecht: Springer.

Dew, N., \& Sarasvathy, S. D. (2016). Exaptation and niche construction: Behavioral insights for an evolutionary theory. Industrial and Corporate Change, 25, 167-179. doi:10.1093/icc/dtv051

Dew, N., Sarasvathy, S. D., \& Venkataraman, S. (2004). The economic implications of exaptation. Journal of Evolutionary Economics, 14, 69-84.

Dewald, U., \& Truffer, B. (2012). The local sources of market formation: Explaining regional growth differentials in German photovoltaic markets. European Planning Studies, 20, 397-420. doi:10.1080/09654313.2012.651803

Dosi, G. (1982). Technological paradigms and technological trajectories. A suggested interpretation of the determinants and directions of technical change. Research Policy, 11, 147-162.

Duymedjian, R., \& Rüling, C.-C. (2010). Towards a foundation of bricolage in organization and management theory. Organization Studies, 31, 133-151. doi:10.1177/0170840609347051

Essleztbichler, J. (2015). Relatedness, industrial branching and technological cohesion in US metropolitan areas. Regional Studies, 49, 752-766. doi:10.1080/00343404.2013.806793

Feldman, M. P., Kogler, D. F., \& Rigby, D. L. (2015). rKnowledge: The spatial diffusion and adoption of rDNA methods. Regional Studies, 49, 798-817. doi:10.1080/00343404.2014.980799

Felin, T., Kauffman, S., Mastrogiorgio, A., \& Mastrogiorgio, M. (2016). Factor markets, actors, and affordances. Industrial and Corporate Change, 25, 133-147. doi:10.1093/icc/dtv049

Fleming, L. (2001). Recombinant uncertainty in technological space. Management Science, 47, 117-132. doi:10.1287/mnsc.47.1.117. 10671

Foray, D., David, P. A., \& Hall, B. (2009). Smart specialisation - The concept (Knowledge Economists Policy Brief No. 9). Brussels: European Commission.

Foray, D., David, P. A., \& Hall, B. H. (2011). Smart specialisation From academic idea to political instrument, the surprising career of a concept and the difficulties involved in its implementation (MTEI-WORKING_PAPER-2011-001). Lausanne: Ecole Polytechnique Federale de Lausanne (EPFL).

Frantzeskaki, N., Castan-Broto, V., Coenen, L., \& Loorbach, D. (Eds.) (2016). Urban sustainability transitions. London: Routledge.

Frenken K., \& Boschma, R. A. (2007). A theoretical framework for economic geography: Industrial dynamics and urban growth as a branching process. Journal of Economic Geography, 7, 635-649. doi: $10.1093 /$ jeg/lbm018

Frenken, K., van Oort, F. G., \& Verburg, T. (2007). Related variety, unrelated variety and regional economic growth. Regional Studies, 41, 685-697. doi:10.1080/00343400601120296

Fuenfschilling, L., \& Binz, C. (2016). Global socio-technical regimes. Paper presented at the 50th SPRU Anniversary Conference, Brighton, UK, 7-9 September 2016.

Fuenfschilling, L., \& Truffer, B. (2014). The structuration of sociotechnical regimes - Conceptual foundations from institutional theory. Research Policy, 43, 772-791. doi:10.1016/j.respol.2013. 10.010

Fuenfschilling, L., \& Truffer, B. (2016). The interplay of institutions, actors and technologies in socio-technical systems. An analysis of transformations in the Australian urban water sector. Technological Forecasting and Social Change, 103, 298-312.

Garud, R., Gehman, J., \& Giuliani, A. P. (2016). Technological exaptation: A narrative approach. Industrial and Corporate Change, 25, 149-166. doi:10.1093/icc/dtv050

Garud, R., Hardy, C., \& Maguire, S. (2007). Institutional entrepreneurship as embedded agency: An introduction to the special issue. Organization Studies, 28, 957-969. doi:10.1177/ 0170840607078958

Garud, R., \& Karnøe, P. (2003). Bricolage versus breakthrough: Distributed and embedded agency in technology entrepreneurship. Research Policy, 32, 277-300. doi:10.1016/S0048-7333 (02)00100-2

Garud, R., Kumaraswamy, A., \& Karnøe, P. (2010). Path dependence or path creation. Journal of Management Studies, 47, 760774. doi:10.1111/j.1467-6486.2009.00914.x

Geels, F. W. (2002). Technological transitions as evolutionary reconfiguration processes: A multi-level perspective and a case-study. Research Policy, 31, 1257-1274. doi:10.1016/S0048-7333 (02)00062-8

Geels, F. W., Hekkert, M. P., \& Jacobsson, S. (2008). The dynamics of sustainable innovation journeys. Technology Analysis and Strategic Management, 20, 521-536. doi:10.1080/09537320802292982

Geels, F. W., Kemp, R., Dudley, G., \& Lyons, G. (Eds.) (2012). Automobility in transition? A socio-technical analysis of sustainable transport. New York: Routledge.

Geels, F. W., \& Raven, R. (2006). Non-linearity and expectations in niche-development trajectories: Ups and downs in Dutch biogas development (1973-2003). Technology Analysis and Strategic Management, 18, 375-392. doi:10.1080/09537320600777143

Gertler, M. S. (2004). Manufacturing culture: The institutional geography of industrial practice. Oxford: Oxford University Press.

Giddens, A. T. (1984). The constitution of society. Outline of the theory of structuration. Cambridge: Polity.

Grabher, G. (1993). The weakness of strong ties - The lock-in of regional development in the Ruhr area. In G. Grabher (Ed.), The embedded firm. (pp. 255-277). London: Routledge.

Grin, J., Rotmans J., \& Schot, J. (2011). On patterns and agency in transition dynamics: Some key insights from the KSI programme. Environmental Innovation and Societal Transitions, 1, 76-81. doi:10.1016/j.eist.2011.04.008

Hansen, T., \& Coenen, L. (2015). The geography of sustainability transitions: Review, synthesis and reflections on an emergent research field. Environmental Innovation and Societal Transitions, 17, 92-109. doi:10.1016/j.eist.2014.11.001

Hassink, R. (2005). How to unlock regional economies from path dependency? From learning region to learning cluster. European Planning Studies, 13, 521-535. doi:10.1080/09654310500107134

Hassink, R., Klaerding, C., \& Marques, P. (2014). Advancing Evolutionary Economic Geography by engaged pluralism. Regional Studies, 48, 1295-1307. doi:10.1080/00343404.2014. 889815 
Heimeriks, G., \& Balland, P.-A. (2015). How smart is specialisation? An analysis of specialisation patterns in knowledge production. Science and Public Policy. doi:10.1093/scipol/scv061

Heimeriks, G., \& Boschma, R. (2014). The path- and place-dependent nature of scientific knowledge production in biotech 19862008. Journal of Economic Geography, 14, 339-364. doi:10.1093/ jeg/lbs052

Hekkert, M. P., Suurs, R. A. A., Negro, S. O., Kuhlmann, S., \& Smits, R. E. H. M. (2007). Functions of innovation systems: A new approach for analysing technological change. Technological Forecasting and Social Change, 74, 413-432. doi:10.1016/j. techfore.2006.03.002

Henderson, D. (2000). EU regional innovation strategies: regional experimentalism in practice? European Urban and Regional Studies, 7, 347-358. doi:10.1177/096977640000700404

Hidalgo, C. A., Klinger, B., Barabasi, A. L., \& Hausmann, R. (2007). The product space and its consequences for economic growth. Science, 317, 482-487. doi:10.1126/science.1144581

Hoogma, R., Kemp, R., Schot, J., \& Truffer, B. (2002). Experimenting for sustainable transport. The approach of strategic niche management. London: Spon.

Hughes, T. P. (1993). Networks of power: Electrification in Western society, 1880-1930. Baltimore: Johns Hopkins University Press.

Isaksen, A., \& Trippl, M. (2014). Regional industrial path development in different regional innovation systems: $A$ conceptual analysis (Papers in Innovation Studies No. 2014/17). Lund: Lund University, Centre for Innovation, Research and Competence in the Learning Economy (CIRCLE).

Karnøe, P., \& Garud, R. (2012). Path creation: Co-creation of heterogeneous resources in the emergence of the Danish wind turbine cluster. European Planning Studies, 20, 733-752. doi:10. 1080/09654313.2012.667923

Kemp, R., Schot, J., \& Hoogma, R. (1998). Regime shifts to sustainability through processes of niche formation: The approach of strategic niche management. Technology Analysis and Strategic Management, 10, 175-198. doi:10.1080/09537329808524310

Klepper, S. (2002). The capabilities of new firms and the evolution of the U.S. automobile industry. Industrial and Corporate Change, $11,645-666$.

Klepper, S. (2007). Disagreements, spinoffs, and the evolution of Detroit as the capital of the U.S. automobile industry. Management Science, 53, 616-631.

Kogler, D. F. (2015). Editorial: Evolutionary Economic Geography Theoretical and empirical progress. Regional Studies, 49, 705-711.

Kogler, D. F., Rigby, D. L., \& Tucker, I. (2013). Mapping knowledge space and technological relatedness in U.S. cities. European Planning Studies, 21, 1374-1391. doi:10.1080/ 09654313.2012.755832

Lévi-Strauss, C. (1967). The savage mind. Chicago: University of Chicago Press.

MacKinnon, D., Cumbers, A., Pike, A., Birch, K., \& McMaster, R. (2009). Evolution in economic geography: Institutions, political economy, and adaptation. Economic Geography, 85, 129-150. doi:10.1111/j.1944-8287.2009.01017.x

Markard, J., Raven, R., \& Truffer, B. (2012). Sustainability transitions: An emerging field of research and its prospects. Research Policy, 41, 955-967. doi:10.1016/j.respol.2012.02.013

Martin, R. (2010). Roepke Lecture in Economic Geography Rethinking regional path dependence: Beyond lock-in to evolution. Economic Geography, 86, 1-27. doi:10.1111/j.1944-8287. 2009.01056.x

Martin, R., \& Sunley P. (2006). Path dependence and regional economic evolution. Journal of Economic Geography, 6, 395-437. doi:10.1093/jeg/lb1012

Mazzucato, M. (2013). The entrepreneurial state. Debunking public vs. private sector myths. London: Anthern.
Mokyr, J. (1990). The lever of riches: Technological creativity and economic progress. New York: Oxford University Press.

Morgan, K. (2013). Path dependence and the state: The politics of novelty in old industrial regions. In P. Cooke (Ed.), Reframing regional development: Evolution, innovation, transition (pp. 318340). London: Routledge.

Morgan, K., \& Henderson, D. (2002). Regions as laboratories: The rise of regional experimentalism in Europe. In M. Gertler \& D. Wolfe (Eds.), Innovation and social learning: Institutional adaptation in an era of technological change (pp. 204-226). London: Palgrave Macmillan.

Murphy, J. T. (2015). Human geography and socio-technical Transition Studies: Promising intersections. Environmental Innovation and Societal Transitions, 17, 73-91. doi:10.1016/j. eist.2015.03.002

Neffke, F., Hartog, M., Boschma, R., \& Henning, M. (2014). Agents of structural change. The role of firms and entrepreneurs in regional diversification (Papers in Evolutionary Economic Geography No. 14.10. Utrecht: Utrecht University.

Neffke F., Henning M., \& Boschma, R. (2011). How do regions diversify over time? Industry relatedness and the development of new growth paths in regions. Economic Geography, 87, 237265. doi:10.1111/j.1944-8287.2011.01121.x

Nelson, R.R., \& Winter, S. G. (1977). In search of useful theory of innovation. Research Policy, 6, 36-76. doi:10.1016/0048-7333 (77) $90029-4$

Nelson, R. R., \& Winter S. G. (1982). An evolutionary theory of economic change. Cambridge, MA: Belknap.

Quatraro, F., \& Montresor, S. (2015). Key enabling technologies and smart specialization strategies. Regional evidence from European patent data. Paper presented at the annual DRUID conference, Rome, Italy.

Quitzow, R. (2015). Dynamics of a policy-driven market: The coevolution of technological innovation systems for solar photovoltaics in China and Germany. Environmental Innovation and Societal Transitions, 17, 126-148. doi:10.1016/j.eist.2014.12.002

Rigby, D. L. (2015). Technological relatedness and knowledge space. Entry and exit of US cities from patent classes. Regional Studies, 49, 1922-1937.

Rip, A., \& Kemp, R. (1998). Technological change. In S. Rayner \& E. L. Malone (Eds.), Human choice and climate change. Resources and technology (pp. 327-399). Columbus: Battelle.

Sabel, C. F. (1996). A measure of federalism: Assessing manufacturing technology centers. Research Policy, 25, 281-307. doi:10. 1016/0048-7333(95)00851-9

Saviotti, P. P., \& Frenken, K. (2008). Export variety and the economic performance of countries. Journal of Evolutionary Economics, 18, 201-218. doi:10.1007/s00191-007-0081-5

Schot, J., \& Geels, F. W. (2008). Strategic niche management and sustainable innovation journeys: Theory, findings, research agenda, and policy. Tecbnology Analysis and Strategic Management, 20, 537-554. doi:10.1080/09537320802292651

Scott, A. J., \& Storper, M. (1987). High technology industry and regional development. A theoretical critique and reconstruction. International Social Science Journal, 112, 215-232.

Sengers, F., \& Raven, R. (2015). Toward a spatial perspective on niche development: The case of bus rapid transit. Environmental Innovation and Societal Transitions, 17, 166-182. doi:10.1016/j.eist.2014.12.003

Simmie, J. (2012). Path dependence and new path creation in renewable energy technologies. European Planning Studies, 20, 729731. doi:10.1080/09654313.2012.667922

Sine, W. D., \& Lee, B. H. (2009). Tilting at windmills? The environmental movement and the emergence of the US wind energy sector. Administrative Science Quarterly, 54, 123-155. doi:10.2189/ asqu.2009.54.1.123 
Smil, V. (2006). Transforming the twentieth century: Technical innovations and their consequences. Oxford: Oxford University Press.

Smith, A., \& Raven, R. (2012). What is protective space? Reconsidering niches in transitions to sustainability. Research Policy, 41, 1025-1036. doi:10.1016/j.respol.2011.12.012

Sotarauta, M., \& R. Pulkkinen (2011). Institutional entrepreneurship for knowledge regions: In search of a fresh set of questions for regional innovation studies. Environment and Planning C, 29, 96-112. doi:10.1068/c1066r

Spaargaren, G., Oosterveer, P., \& Loeber, A. (Eds.) (2012). Food practices in transition: Changing food consumption, retail and production in the age of reflexive modernity. New York: Routledge.

Späth, P., \& Rohracher, H. (2012). Local demonstrations for global transitions. Dynamics across governance levels fostering sociotechnical regime change towards sustainability. European Planning Studies, 20, 461-479.

Stinchfield, B. T., Nelson, R. E., \& Wood, M. S. (2013). Learning from Levi-Strauss' legacy: Art, craft, engineering, bricolage, and brokerage in entrepreneurship. Entrepreneurship Theory and Practice, 37, 889-921. doi:10.1111/j.1540-6520.2012.00523.x

Storper, M., \& Walker, R. (1989). The capitalist imperative: Territory, technology and industrial growth. New York: Basil Blackwell.

Sydow, J., Windeler, A., Müller-Seitz, G., \& Lange, K. (2012). Path constitution analysis: A methodology for understanding path dependence and path creation. BuR - Business Research, German Academic Association for Business Research (VHB), 5, 155-176.

Tanner, A. N. (2014). Regional branching reconsidered: Emergence of the fuel cell industry in European regions. Economic Geography, 90, 403-427. doi:10.1111/ecge.12055

Tanner, A. N. (2016). The emergence of new technology-based industries: The case of fuel cells and its technological relatedness to regional knowledge bases. Journal of Economic Geography, 16, 611-635. doi:10.1093/jeg/lbv011
Trippl, M., Grillitsch, M., \& Isaksen, A. (2015). External 'energy' for regional industrial change: Attraction and absorption of non-local knowledge for new path development (Papers in Innovation Studies No. 2015/47). Lund: Lund University, Centre for Innovation, Research and Competence in the Learning Economy (CIRCLE).

Truffer, B., \& Coenen, L. (2012). Environmental innovation and sustainability transitions in regional studies. Regional Studies, 46, 1-21. doi:10.1080/00343404.2012.646164

Truffer, B., Murphy, J. T., \& Raven, R (2015). The geography of sustainability transitions: Contours of an emerging theme. Environmental Innovation and Societal Transitions, 17, 63-72. doi:10.1016/j.eist.2015.07.004

Vallance, P. (2016). Universities, public research, and Evolutionary Economic Geography. Economic Geography, 92, 355-377. doi:10.1080/00130095.2016.1146076

Verbong, G., \& Geels, F. (2012). Future electricity systems: Visions, scenarios and transition pathways. In G. P. J. Verbong \& D. Loorbach (Eds.), Governing the energy transition: Reality, illusion or necessity? (pp. 203-219). New York: Routledge.

Wenting, R., \& Frenken, K. (2011). Firm entry and institutional lock-in: An organizational ecology analysis of the global fashion design industry. Industrial and Corporate Change, 20, 10311048. doi:10.1093/icc/dtr032

Winter, S. G., \& Szulanski, G. (2001). Replication as strategy. Organization Science, 12(6), 730-743.

Xiao, J., Boschma, R., \& Andersson, M. (2016). Industrial diversifcation in Europe: The differentiated role of relatedness (Papers in Evolutionary Economic Geography No. 16.27). Utrecht: Utrecht University.

Yeung, H. W., \& Coe, N. M. (2015). Toward a dynamic theory of global production networks. Economic Geography, 91, 29-58. doi:10.1111/ecge.12063 